O. Cherednik, T. Dmytrenko, T. Derkach

National University «Yuri Kondratyuk Poltava Polytechnic», Poltava, Ukraine

\title{
INTELLIGENT MODEL DEVELOPMENT FOR RECOGNIZING EMOTIONS IN TEXT
}

\begin{abstract}
The topical issue of human emotions recognition in the text is considered. The offers of available products on the market that offer similar functionality are analyzed. The possibilities of implementing the model for recognizing emotions in the text are investigated. The program functions interact with the model and the requirements for the model itself are determined. The steps sequence for obtaining data for training the model and its own implementation is given. The developed architectural model is presented, the programming language use is selected and substantiated, the methods and approaches use for training the model is selected and justified, the initial data and options sources for obtaining data for training the model are considered. A model and a data set for it are proposed, which will make it possible to obtain recognition of some emotions in the text with a certain accuracy. Particular attention is paid to the possibility of developing the application and improving this approach and model in the future for the possibility of using machines to better serve people, understanding the consumer, measuring the happiness level among the population, understanding the audience mood.
\end{abstract}

Keywords : recognition of emotions in the text, intelligent model, semantic analysis of the text, model building.

\section{Introduction}

More and more work nowadays is being done in industries such as machine language translation, Chatbots, text classification (sentiment analysis, topic naming) and many others.

Considering the data amount in the world is growing every year, the areas where it would be advisable to process such data and use the processing results are also increasing.

Emotions take an important part in communication when people interact with each other, but machines cannot understand these emotions. Therefore, determining the emotion type will play an important role in the future humans interaction with machines. Emotion detection can have useful applications, such as:

- Understanding the person's condition to better serve the person.

- Understanding of the user, and as a consequence of improving the user with the ultimate goal of increasing brand reputation and sales.

- Measuring the happiness level among the population.

- Understanding the audience mood. Can be applied to social networks, forums, chats, etc.

\section{Problem statement}

The study objective is to design and programmatically implement a model for recognizing certain emotions in the text.

Appointment of an intelligent model for recognizing emotions in the text. The main purpose of this model is to recognize six main emotions categories that are widely used to describe the basic people emotions: happiness, sadness, anger, disgust, surprise, fear.

The creating purpose an intelligent model for recognizing emotions in the text. The goal is to build and model with the subsequent possibility of using it to better serve machines to people, understanding the consumer, measuring the happiness level among the population, understanding the audience mood and other similar areas.
The target audience of the intellectual model for recognizing emotions in the text. Target audience: scientists, developers, entrepreneurs and people are interested in such functionality.

\section{Material and research results}

Existing information products review with similar functionality on the market. To create an intelligent model for recognizing emotions in the text, an analysis of existing services and products was carried out.

Here are a few of the reviewed products:

1. TwinWord is an API that allows you to highlight one of six emotions (anger, disgust, fear, happiness, sadness, and surprise) in a text paragraph. Used in conjunction with AWS and RapidAPI where requests are sent and after they are processed, we receive a response with emotional ratings and emotion that was detected (Fig. 1)[1].

2. Text analytics by Microsoft [2]. Text analytics from Microsoft enables you to(Fig. 2):

- determine the text tonality (positive, neutral and negative)

- determine the text language and the confidence in this assumption;

- highlighting key phrases in not very structured text.

3. IBM Watson Tone Analyzer [3]. This service may analyze social media posts, emails, French product views, and personal text. As a result, we will receive a list of emotions present in this text (anger, fear, joy, sadness, I am sure). You can also consider in more detail each proposal for the presence of a particular emotion (Fig. 3).

4. MonkeyLearn sentiment analysis [4]. The service is focused on anticipating the sentimental content of the offer, without highlighting the emotions. As a result, it returns one of three values (positive, neutral, negative) (Fig. 4).

The currently existing services analysis showed the relevance of developing an intelligent model for recognizing emotions in text and programs. With the such a 
program help, it will be possible to interact with this model and the such interaction result will be the definition in the text of one or another emotion from six basic emotions (anger, fear, joy, sadness, I am sure).

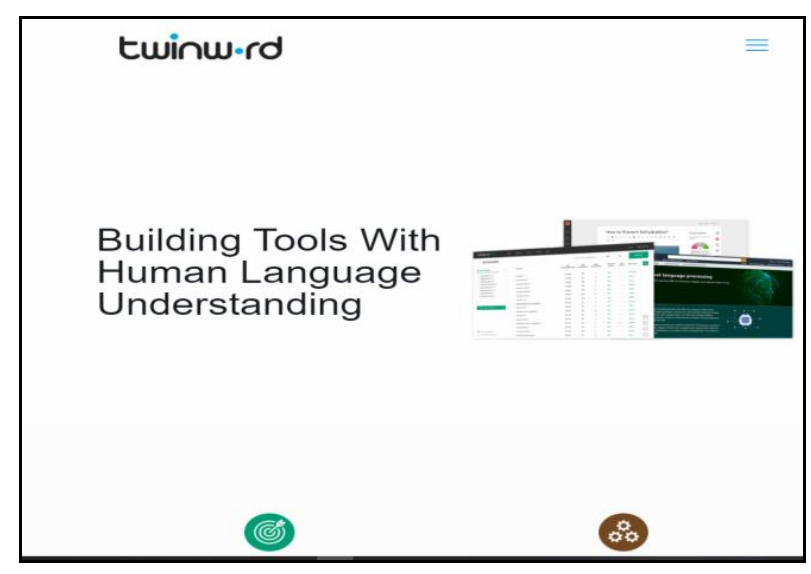

Fig. 1. TwinWord interface

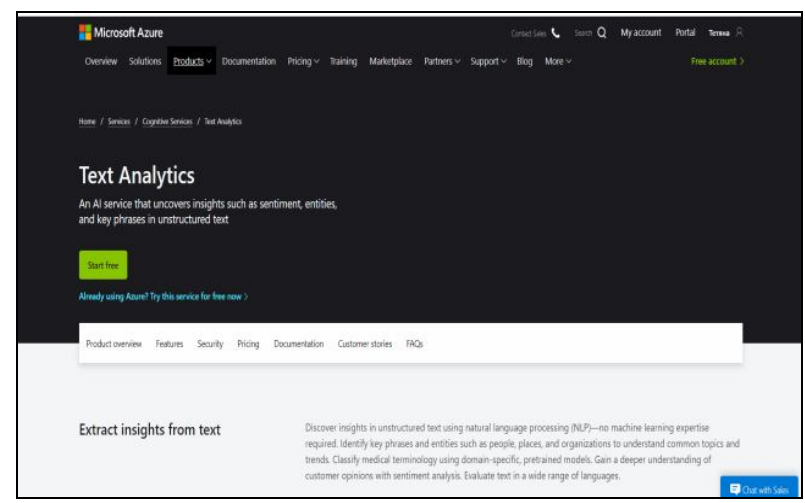

Fig. 2. Text analytics by Microsoft interface

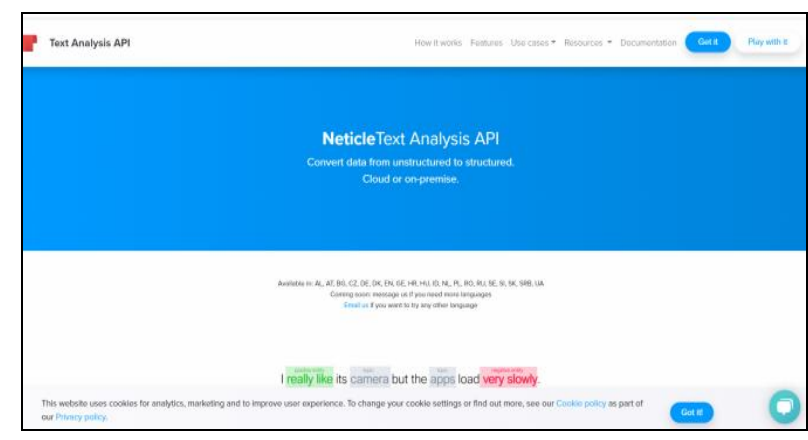

Fig. 3. IBM Watson Tone Analyzer interface

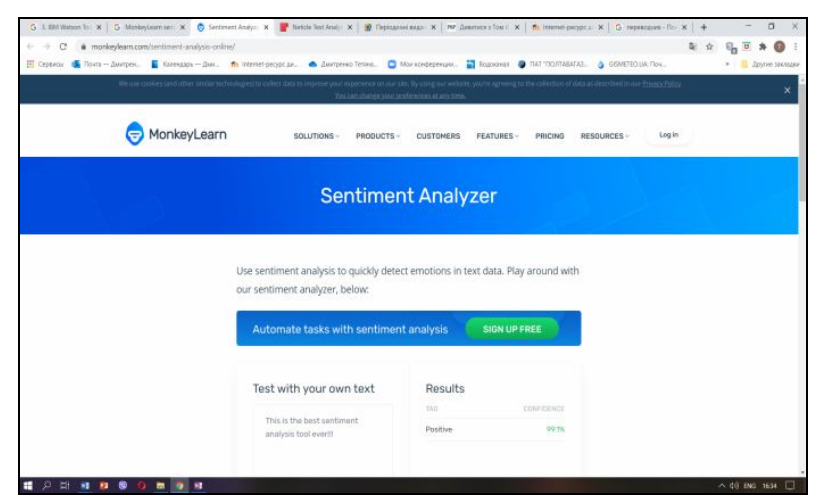

Fig. 4. MonkeyLearn sentiment analysis interface

\section{Tools selection of and approaches to implementation with their justification}

First, let's think about a sentiment analysis tool where we can anticipate the sentence polarity. Let's consider the following message: "I'm so happy that I did all the work today on time :) \#happy". We can say that this proposal has a positive meaning.

Such a tool can be used to view products on social media data. Another way to use it is to anticipate a company's reputation based on what users say.

Sentiment analysis is a good tool if we just want to test the sentence polarity. But the purpose of this work is to define a specific emotion, but only polarity, so in this work there will be little sentiment analysis.

So specific emotions predictions that a specific text carries within it will be realized. With the emotion recognition help, you can get more detailed data about what exactly the user felt at the moment of this particular message, etc., which means that the application is wider.

It is for the emotions recognition in the text that neural networks will be used.

For semantic analysis, one can use SENN [5] (Semantic-Emotion Neural Network) or Bidirectional GRU [6] (Gated recurrent unit).

SENN can use both semantic / syntactic and emotional information by accepting pre-trained word representations. The SENN model has basically two subnets, the first subnet uses bi-directional long-term short-term memory to gather contextual information and focuses on semantic relationships, the second subnetwork uses $\mathrm{CNN}$ [7] (Convolutional neural network) to extract emotional characteristics and emphasizes the emotional relationship words from the text.

In this case, the Bidirectional GRU model will be used for semantic analysis of the data that will be received from Twitter.

For the architecture of a machine learning model for emotion recognition, Bidirectional RNN (Recurrent Neural Networks) [8] LSTM (Long short-term memory) [9] with CNN level will be used.

The idea is that the LSTM layer captures information about the context of the proposal, while CNN grabs local specifics.

A dataset for training a smart model. To train an intelligent model, you need to have a dataset labeled with the corresponding emotions. The datasets include such filtered sets as:

- Sentiment Analysis: Emotion in Text[10] Data[11];

- Complete Tweet Sentiment Extraction

- The GoEmotions dataset[12];

- Downloaded and filtered users posts from Twitter

Programming language. In my experience, the two most popular programming tools for working with data science are Python [13] and R [14]. It is difficult to choose one of these two extremely flexible data analysis languages. Both are free and open source and were developed in the early 1990 s. R for statistical analysis and Python for general tasks. 
A wide libraries and frameworks range for machine learning, simplifies the development process and reduces development time. Python's simple syntax and readability make it quicker to test complex algorithms and make the language accessible to non-programmers.

Python is a powerful, versatile language that programmers can use for a variety of computer science tasks, so this project will be done using Python and tools as related.

Training an intelligent model. Having a dataset labeled with emotion is being trained, we move on to building a model to predict emotions in the text.

Model training process:

- data is filtered,

- prepared data is divided into a training dataset and a dataset for testing (in a ratio of $70 \%$ to $30 \%$ ).

- Training and validation datasets are used to train the classifier and optimize its parameters, while a test dataset (invisible to the model) is reserved for model testing to indicate how well the model is trained;

- the model is initialized;

- starting training for a certain number of epochs and checking the accuracy of the model with subsequent correction (Fig. 5).

When developing a software product and training an intelligent model, modern technologies were selected and substantiated, which make it possible to perform the assigned task with the least amount of time and a fairly good result.

\section{Conclusions}

The research results are: an intelligent model for recognizing emotions in the text and a console program that makes it possible to interact with the specified model.

The program result is the percentage probability of the sentence belonging to one or another of the above emotions.

The console program works in one of two modes:

- the text analysis in a given document, which contains a list of sentences in which the emotion should be defined (Fig. 6);

- interactive mode: when the user enters a sentence from the console and receives the output of the program back to the terminal (Fig. 7).

The data set on which the intelligent model was trained played an important role in achieving the research goal.

As a result, the model accuracy was about $60 \%$ (Fig. 8), but this is not the maximum possible indicator.

Some ways you can improve the model result.

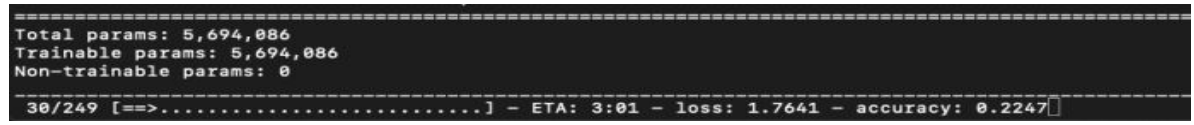

Fig. 5. Model training process

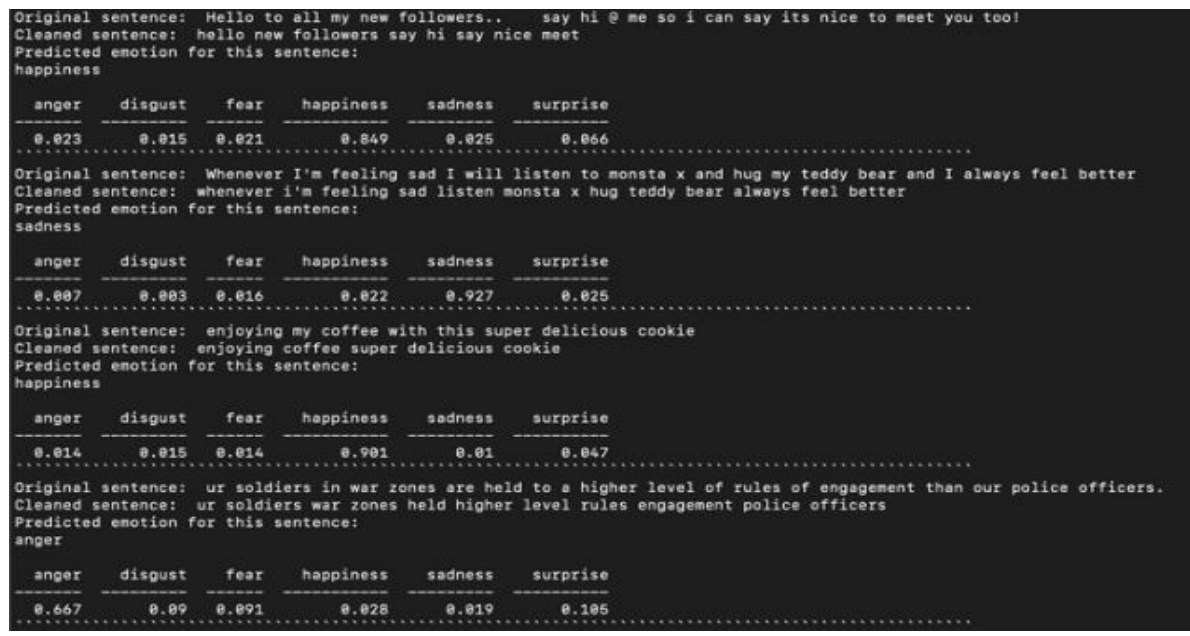

Fig. 6. Definition of emotions in the list of sentences in a given document

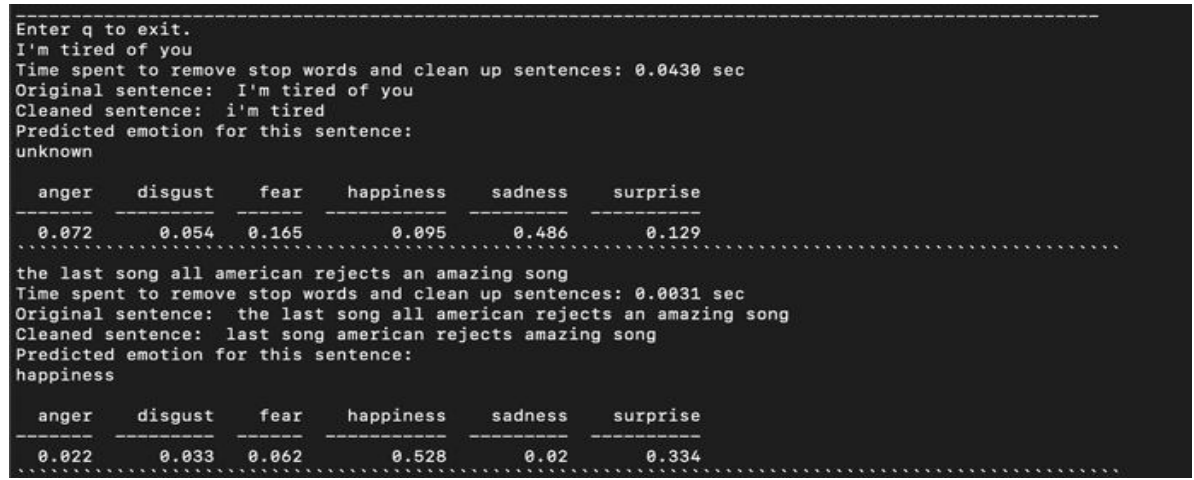

Fig. 7. Emotions determination in the user's proposal interactively 


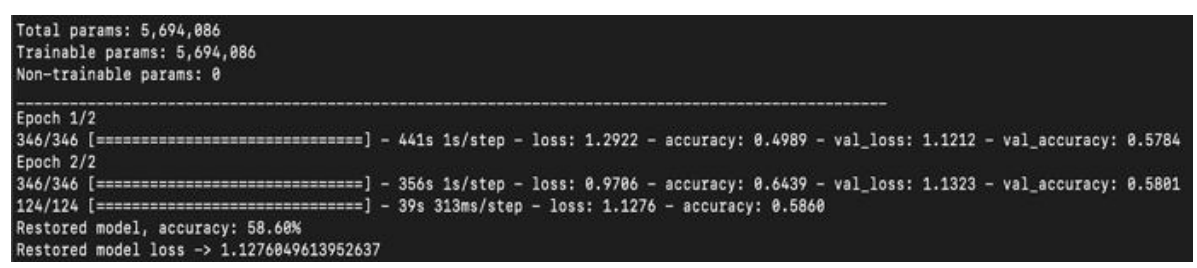

Fig. 8. Trainthemodel.

One important aspect to explore is espatially the dataset. You can balance the samples distribution for each emotion (giving each emotion equal samples).

- Collect test data for verification, that is, designate each user's post one by one so that the test set better reflects reality;
- Manually label the entire dataset with appropriate emotions;

- The examples number in the dataset may be larger.

Thus, the accuracy can be better.

\section{REFERENCES}

1. Emotion Analysis:[Електронний ресурс].- Режим доступа: https://www.twinword.com/api/emotion-analysis.php (дата звернення 30.08.2020). - Назва з екрана.

2. Text analytics by Microsoft: [Електронний ресурс]:-Режим доступа: https://azure.microsoft.com/ru-ru/services/ cognitiveservices/text-analytics/\#features (дата звернення 14.08.2020). - Назва з екрана.

3. IBM Watson Tone Analyzer:[Електронний ресурс].- Режим доступа:https://tone-analyzer-demo.ng.bluemix.net(дата звернення 25.09.2020). - Назва з екрана.

4. MonkeyLearn sentiment analysis:[Електронний ресурс].- Режим доступа: https://monkeylearn.com/sentimentanalysis(дата звернення 30.09.2020). - Назва з екрана.

5. Batbaatar E. Semantic-Emotion Neural Network for Emotion Recognition From Text /E.Batbaatar, M.Li and Ryu K.H. // IEEE Access. - vol. 7. -2019.-pp. 111866-111878, doi: 10.1109/ACCESS.2019.2934529.

6. Gruber,N. Are GRU cells more specific and LSTM cells more sensitive in motive classification of text?/ Gruber,N.; Jockisch A. //Frontiers in Artificial Intelligence.- № 3-2020. doi:10.3389/frai.2020.00040.

7. Aurélien GéronHands-on Machine Learning with Scikit-Learn, Keras, and TensorFlow.- Sebastopol, CA: O'Reilly Media. 2019. -pp. 448.

8. Saon, G., \& Picheny, M. (2017). Recent advances in conversational speech recognition using convolutional and recurrent neural networks. IBM Journal of Research and Development, 61(4/5), 1-1.

9. Gupta A. et al. Generative recurrent networks for de novo drug design //Molecular informatics. - 2018. - T. 37. - №. 1-2. C. 1700111.

10. Sentiment Analysis: Emotion in Text:[Електронний ресурс].- Режим доступа: https://www.kaggle.com/c/sa-emotions/data (дата звернення 01.11.2020). - Назва з екрана.

11. Complete Tweet Sentiment Extraction Data:[Електронний pecypc].- Режим доступа: https://www.kaggle.com/maxjon/complete-tweet-sentiment-extraction-data

12. The GoEmotions dataset:[Електронний pecypc].- Режим доступа: https://github.com/google-research/googleresearch/tree/master/goemotions (дата звернення 17.07.2020). - Назва з екрана.

13. Python is a programming language that lets you work more quickly and integrate your systems more effectively:[Електронний ресурc].- Режим доступа:: https://www.python.org/ (дата звернення 20.09.2020). - Назва 3 екрана

14. Ben M. Packaging data analytical work reproducibly using R (and friends) / M. Ben, C. Boettiger and L. Mullen // The American Statistician. -№ 72.1. - (2018).- p. 80-88.

Received (Надійшла) 12.10.2020

Accepted for publication (Прийнята до друку) 11.11.2020

\section{Розробка інтелектуальної моделі по розпізнаванню емоцій в тексті}

О. С. Чередник, Т. А. Дмитренко, Т. М. Деркач

Анотація. У статті запропоновано модель і набір даних для неї, які дозволять отримати розпізнавання деяких емоцій в тексті з певною точністю. Предметом вивчення в статті є модель по розпізнаванню емоцій в тексті. Метою статті є дослідження та побудова моделі по розпізнаванню емоцій в текстіз подальшою можливістю застосування для кращого розуміння споживача, вимірювання рівня щастя у населення, розуміння настрою аудиторії і інших схожих сферах. Задача, що вирішується. Досліджено можливості реалізації моделі для розпізнавання емоцій в тексті. Визначено функції програми, яка буде взаємодіяти з моделлю і вимоги до самої моделі. В статті розглядається: актуальне питання розпізнавання емоцій людини в тексті. Проаналізовано пропозиції наявних продуктів на ринку, які пропонують схожий функціонал. Наведено послідовність кроків отримання даних для тренування моделі і власної реалізації. Особлива увага звертається на можливості розвитку застосування і поліпшення даного підходу. Висновки. Представлено розроблену архітектуру моделі, обрано та обгрунтовано використання мови програмування, обрано та обгрунтовано використання методів і підходів для тренування моделі, розглянуті джерела вихідних даних та варіанти отримання даних для тренування моделі.

Ключов і слов а : розпізнавання емоцій у тексті, інтелектуальна модель, семантичний аналіз тексту, побудова моделі. 